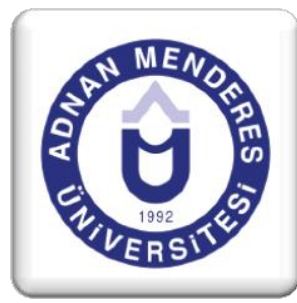

\title{
Eleştirel Düşünme Eğitiminin Müzik Eğitiminde Performansa Etkisi
}

\section{The Effect of Critical Thinking on Performance in Music Education}

\author{
Gülce COŞKUN ŞENTÜRK ${ }^{1}$
}

\section{Özet}

Bu çalışmanın genel amacl; eleştirel düşünme eğitiminin müzik eğitiminde çalgı performansına etkilerini araştırmaktır. Bu amaç doğrultusunda, deneysel araştırma modellerinden ön test-son test kontrol gruplu deneme modeline göre bir araştırma deseni oluşturulmuştur.Söz konusu araştırmada, 2009-2010 öğretim yılı bahar döneminde, Gazi Üniversitesi Gazi Eğitim Fakültesi Güzel Sanatlar Eğitimi Bölümü Müzik Eğitimi Anabilim Dalı'nda okuyan ve yaşları 19 - 23 arasında değişen (Ort. = 20.85 , ss $=1.08$ ), 26'sı flüt ve 14'ü piyano ögrencisi olmak üzere toplam 40 ögrenci (38 kız, 2 erkek) üzerinde çalışılmıştır. Araştırmaya katılan, toplam 40 öğrenciye Demografik Bilgi Anketi ve California Eleştirel Düşünme Ölçeği Türkçe Versiyonu'ndan oluşan bir soru bankası sunulmuştur. Katılımcılar söz konusu sorulara yanıt verdikten sonra, alanlarında uzman olan 3 flüt ve 1 piyano olmak üzere toplam 4 müzik eğitimcisi tarafından Performans Değerlendirme Sınavına tabi tutulmuştur. Katılımcılar daha sonra, deney ve kontrol olmak üzere 2 gruba ayrılmışlardır. Deney grubuna araştırmacı tarafından hazırlanan Eleştirel Düşünme Eğitimi verilirken, kontrol grubunda yer alan katılımcılar bu eğitimi almayarak, Yükseköğretim Kurulu (YÖK) tarafından kabul edilmiş olan 2005 yılı müzik eğitimi programındaki dersler doğrultusunda, müzik eğitimlerine devam etmişlerdir. Son aşamada, her iki gruptan da ilk başta verilen California Eleştirel Düşünme Eğilimi Ölçeği Türkçe Versiyonu'ndan oluşan soru bankasını yeniden yanıtlamaları istenmiştir. Ardından her iki grup tekrar aynı jüri tarafından Performans Değerlendirme Sınavı'na tabi tutulmuştur.

Araştırma kapsamındaki deney grubu ve kontrol grubu üzerinden elde edilen veriler, SPPS paket programı ile çözümlenmiştir. Verilerin aritmetik ortalamaları ve standart sapmaları betimsel olarak verildikten sonra, deney ve kontrol gruplarının ön test - son test puanları arasında fark olup olmadığını belirlemek için varyans analizi (son faktörde tekrar ölçümlü) kullanılmıştır. Araştırmanın sonuçlarına bakıldığında;eleştirel düşünme eğitiminin, katılımcıların performans puanlarını yükselttiği görülmektedir.

Anahtar Kelimeler: Eleştirel Düşünme, California Eleştirel Düşünme Ölçeği, Müzik Eğitimi, Performans.

\footnotetext{
${ }^{1}$ Yrd. Doç .Dr.Muğla Sıtkı Koçman Üniversitesi Eğitim Fakültesi Güzel Sanatlar Eğitimi Bölümü Müzik Eğitimi Anabilim Dalı

Bu makale, Gülce COŞKUN’un “Eleştirel Düşünme Eğitiminin Müzik Eğitiminde Performansa Etkisi” isimli doktora tezinden özetlemiştir.
} 


\begin{abstract}
The aim of this study is to determine the effects of critical thinking on playing musical instruments. In light of this aim, the pretest-posttest design has been implemented in carrying out the study using control groups. The aforesaid research has been carried out with a total of 40 students (38 female, 2 male) that had studied at Gazi University, Department of Fine Arts Education, Music Education Program in the 2009-2010 academic year; the age of which differed between 19 and $23(M=20.85, S D=1.08)$ and 26 of which played the flute while 14 of which played the piano. The Turkish versions of the Demographic Information Survey and California Critical Thinking Test have been applied to all forty students that have participated in the study. After that they have been put through the Performance Evaluation Test by 4 field experts (3 flutists, 1 pianist). Next, the group was divided in to two groups; the experimental group and the control group namely. The experimental group has been put through a Critical Thinking education by the researcher whereas the control group has continued their educational program in the field of Music Education set by the Higher Education Council. In the final phase of the study, both groups were asked to retake the Turkish version of the California Critical Thinking Test. Later both groups were re-evaluated by the aforementioned experts using the Performance Evaluation Test.
\end{abstract}

The data collected from the experimental and the control groups were analyzed through the Statistical Package for Social Sciences. After presenting the arithmetic means and the standard deviations of the data; variance evaluation analysis has been carried out to determine whether there is a difference between these results and the results gathered through the pre-, ${ }^{1}$ post-test design points. When we look at the results of the study;it is evident that critical thinking education increases the performance points of the attendees.

Keywords: Critical Thinking, California Critical Thinking Scale, Music Education, Performance.

\title{
1.Giriş
}

Eğitim kavramı, bireylerin içinde yaşadıkları topluma uyum sağlama sürecinde doğrudan ya da dolaylı olarak karşımıza çıkar. Eğitim, bütün yönleri ve bütün işlevleriyle; bireye sosyal, ekonomik ve kültürel bakış açıları kazandırarak, bireyin sürekli olarak değişmesini ve gelişmesini sağlar. Özellikle 21. yüzyılda; sosyal, kültürel, ekonomik ve teknolojik alanlardaki hızlı değişim, eğitim alanına; dolayısıyla bireylere de yansımaktadır. İște bu sebeple eğitimin tanımı, eğitimin amacı, çağın gereklerine göre hızla yeniden şekillenmektedir.

"Toplum ve insan ilişkileri açısından, toplumsal, kültürel ve ekonomik kalkınmanın temel etkenlerinden biri olarak kabul edilen eğitimin genel amacı, bireylerin içinde yaşadıkları topluma sağlıklı bir şekilde uyum sağlamalarına yardım etmektir. Bu yönüyle de eğitim, hem çevresini etkilemekte hem de çevresinden etkilenerek sürekli gelişmektedir. 21. yüzyıl eğitimi, esneklik, kendi kendine öğrenme, olaylara geniş bir açıdan bakabilme, eleştirel düşünebilme ve yaratıcı problem çözme yeterliliğine sahip vatandaşlar gerektirmektedir” (Kepenekçi, 2000: 39). 
Bu gereksinim ve değişimin yansımaları günümüz eğitim sistemlerinin amaçlarına bakıldığında açıkça görülmektedir. Önceleri daha çok geleneksel bir yaklaşımla yapılan programlar, yerini daha bilimsel, daha sorgulayıcı ve daha araştırmacı olan çağdaş programlara, dolayısıyla da çağdaş eğitime bırakmaktadır. Bilindiği üzere çağdaş eğitim; bilimsel, yaratıcı, insan haklarına saygıllı, araştırmacı, sorgulayıc1, özgür ve üretici bireyler yetiştirmeyi amaçlayan, aynı zamanda bireyde eleştirel düşünebilme ve problem çözebilme yetisini geliştiren öğrenci merkezli bir yaklaşımdır.

Çağımızın gereği olan bu yaklaşım günden güne eğitim programlarımızda yerini alırken, 21. yüzyıl eğitiminin amaçlarında yer alan esneklik, kendi kendine öğrenme, olaylara geniş bir açıdan bakabilme, eleştirel düşünebilme ve yaratıcı problem çözme gibi kavramlar, sadece eğitimde değil, yaşamın her boyutunda sıklıkla kullanılmaya başlamıştır.

Eleștirel düşünme kavramının eğitim programlarında yerini aldığı, Millî Eğitim Bakanlığı'nın 2004 yılında yapılandırmaya başladığı ve 2006 yılında uygulamaya geçirdiği İlköğretim programında da açıkça görülmektedir.

Millî Eğitim Bakanlığı Talim ve Terbiye Kurulu'nun 12.07.2004 tarih ve 114, 115, 116, 117, 118 sayılı kararları ile kabul edilen ilköğretim programı 2005-2006 eğitim öğretim yılında uygulanmaya başlanmıştır (Millî Eğitim Bakanlı̆̆g [MEB], 2005). Bilimsel düşünen, anlayan, araştıran, inceleyen, eleştiren, sorgulayan ve yorumlayan bireyler yetiştirmek, yeni ilköğretim programlarının temel aldığ görüşlerdendir (MEB, 2005). Ancak bireyleri bu özelliklerle donatacak olan öğretmenlerimizin bu konudaki eğilim ve yeterlilikleri önemli bir husus olarak karşımıza çıkmaktadır.

Yeterliliklerin belirlenmesi ve eğilimlerinin arttırılması adına herhangi bir bilim dalı fark etmeksizin bütün alanlar için önem taşıyan, bireylerde hayata dair bakış açısı oluşturan düşünme sisteminin öğrenilmesi gerekmektedir.Bu sistemin bir parçası olan öğretmen sorgulayıcı, araştırıcı, inceleyici, yorumlayıc1, yeni fikirlere açık, alternatifleri değerlendiren ve yaratıcı düşünebilen bir eğitimci olmaktadır. Bireylerin bahsedilen eleştirel düşünme yetilerini kazanabilmeleri için, düşünme ve eleştirel düşünme kavramlarını sorgulayarak incelemesi ve irdelemesi gerekmektedir. Buradan hareketle, düşünme ve eleştirel düşünme kavramlarına kısaca değinmek gerekmektedir.

\section{Düsünme}

Türk Dil Kurumu [TDK], Türkçe Sözlüğünde (2005: 592) düşünmek; bir sonuca varmak amaciyla bilgileri incelemek, karşılaştırmak ve aradaki bilgilerden yararlanarak düşünme üretmek, zihinsel yetiler oluşturmak, muhakeme etmek olarak tanımlanmaktadır.

Aristoteles'e göre düşünme, insanı hayvandan ayıran belirgin bir özniteliktir, kişinin bağımsız ve kendine özgü eylemidir. Karşılaştırmalar yapma, ayırma, birleştirme, bağlantıları ve biçimleri kavrama yetisidir (Akt; Kökdemir, 1999: 632). Thomson ise düşünmeyi; anımsama, zihinde arayıp bulma, akıl yürütme, sorun çözme ve eleştiriye yönelik "zihinsel süreç" olarak tanımlamaktadır (Taşc1, 2005: 75).

Düşünmenin bilim alanları içerisinde farklı birçok tanımı olsa da, bütün tanımlar ortak bir noktada kesişmektedir. Düşünme, insanı insan yapan ve diğer canlılardan ayıran en temel özelliktir. Çünkü düşünme; öğrenilen, öğretilen ve geliştirilen bir beceridir. Bu becerinin geliştirilmesinde en büyük sorumluluk eğitim kurumlarına düşmektedir.

“... Bu nedenle düşünme yeteneği geliştirilmelidir. İnsan, ancak düşünme gücü geliştirilerek bütün çevresi ile barışık yaşayabilir. İnsanla ilgili bilimler, düşüncenin belli aşamalardan geçerek şekillendiğini, kimi ortamlarda gelişmenin çok yetersiz kaldığını dile getirmektedir. Eğitim ekonomistleri, düşünme eğitimi adına yapılan yatırımların karşılıklarının fazlası ile alınacağı kanısındadırlar. Eğitim felsefecileri, ancak düşünme yeteneğini geliştirerek insanın kendisini gerçekleştirebileceğini, varlık ve olayların anlamlarını bu şekilde kavrayabileceğini düşünmektedirler. Eğitim sosyologları, toplum koşulları da dikkate alınarak düşünme eğitimi verilmesi gerektiği inancindadırlar" (Çakmak, 2002: 51).

Türkiye'deki eğitim programlarının ve ders içeriklerinin düşünme gereksinimlerine imkân sağlamaktan uzak olması, eğitimin daha çok ezbere dayalı yapılması ve eleştirel düşünmenin beceri haline dönüştürülmesine olanak sağlamaması yönüyle sıklıkla eleştirilmektedir. Ülkemizde ve gelişmiş ülkelerin birçoğunda bu konuyla ilgili çalışmalar ve araştırmalar yapılmaktadır. 


\section{Elestirel Düsünme}

Eleştirel düşünmenin herhangi bir bilim dalı fark etmeksizin, bütün alanlar için önem taşıyan, bireylerde hayata dair yeni bir bakış açısı kazandıran bir düşünme boyutu olduğu söylenebilir. Kişinin bu boyutun içerisine girdikçe farklılaştığı ve davranış değişikliğinde bulunmaya başladığı, tutarlı hareket ettiği, öne sürülen iddiaları destekleyen nedenleri, kanıtları araştırıp, ön bilgileri kullandığı ve akademik başarısının yükseldiği yapılan çalışmalarda ortaya konmuştur (Kökdemir, 2003a: 112). Gibson da (1995), eleştirel düşünmenin ne olduğunu ve eleştirel düşünme kavramının ortaya çıkışını, aşağıdaki gibi özetlemiştir.

"Eleştirel düşünme kavramı, felsefe ve psikoloji gibi iki ana disiplin temel alınarak açıklanmaya çalışılmışıı. Felsefi yaklaşım iyi düşünmenin normları, insan düşüncesi kavramı ve gerçekçi, tarafsız bir dünya görüşü için gerekli olan zihinsel beceriler üzerinde odaklanırken, psikolojik yaklaşımlar düşünce ve düşünmeyi temel alan deneysel çalışmalar, karmaşık görüşlerin öğrenilmesindeki bireysel farklılıklar ve eleştirel düşünmenin bir parçası olan problem çözme kavramı üzerinde odaklanmıştır" (Gibson, 1995: 27).

Eleştirel düşünme konusunda yapmış olduğu çalışmalarıyla tanınan Paul (1992), eleştirel düşünmeyi "kişinin kendi düşünmesini iyileştirmek için, düşünme eylemini gerçekleştirirken bunun üzerinde düşünmesi" olarak tanımlamakta ve bu tanımda iki şeyin oldukça önemli olduğunu belirterek, bunları şu şekilde açıklamaktadır;

- Eleştirel düşünme sadece bir düşünme değil, aynı zamanda kendi kendini geliştirmek için nelerin gerekli ve etkili olduğunu ortaya çıkarmaktır.

- Kendi kendini geliştirme ise, bireyin düşünürken kullanacağ ilgilidir. Bir diğer deyişle, standartlar yoluyla kendi düşünme biçimini geliştirmesidir.

Ülkemizde Yüksek Öğretim Kurulu'nun ulusal tez merkezinde yapılan araştırmalarda ve bilimsel yazında bulunan eleştirel düşünme tanımlarından bazıları şunlardır;

- "Eleştirel düşünme; kendi düşüncemizi ve başkalarının fikirlerini daha iyi anlayabilmek ve düşünceleri açıklayabilme becerimizi geliştirmek için gerçekleştirilen etkin, örgütlü ve işlevsel bir bilişsel süreç olarak tanımlanabilir" (Chaffee, 1992; Akt; Kökdemir, 1999).

- "Eleştirel düşünme kendi düşünce süreçlerimizin bilincinde olarak, başkalarının düşünce süreçlerini göz önünde tutup, öğrendiklerimizi uygulayarak, kendimizi ve çevremizde yer alan olayları anlayabilmeyi amaç edinen etkin ve organize zihinsel bir süreçtir” (Cüceloğlu, 1995: 211).

- "Eleştirel düşünme; olguları analiz etme, düşünce üretme ve onu örgütleme, görüşleri savunma, karşılaştırmalar yapma, çıkarımlarda bulunma, tartışmaları değerlendirme ve problem çözme yeteneğidir" (Chance, 1986: 236).

- "Eleştirel düşünmeden kasıt; okunan, bulunan ya da söylenen bilgiler hakkında mutlak bir sonuca varmak yerine, alternatif açıklamalar olabileceğini de göz önünde bulundurmaktır" (Kökdemir, 2003b).

Yapılan bütün tanımlamalar, eleştirel düşünmenin boyutlarını ve kapsamını ortaya koymaktadır. Tek bir yönden kurtulup, birçok yönden bakabilmeyi sağlayan eleştirel düşünme, karşıt düşüncelere de önem veren, sorgulayıcı, araştırıcı ve yaratıcı düşünmeyi sağlar. Bu bağlamda eleştirel düşünme şöyle de ifade edilebilir;

Eleştirel düşünme; düşüncelerin derinliğinde daha sorgulayıcı ve etkin olabilmek için temelde güvenilir ve geçerli bilgi ile farklı bakış açılarına yer veren, böylelikle çeşitlenerek zenginleşen, yorum yapmamıza olanak sağlayan, zihnin "neden" "niçin" ve "nasıl" sorularına cevap arayan düşünsel bir süreçtir. 


\section{Elestirel Düsünmenin Ë̆itimde Kullanımı}

Eleştirel düşünme ve akademik başarının ilişkilendirilmesi, yapılan birçok araştırmada inceleme konusu olmuş [Akbıyık: 2002, Deniz: 2003,Kökdemir: 2003b vb.] ve eleştirel düşünme gücü yüksek olan bireylerin akademik başarılarının daha yüksek olduğu görülmüştür. Yapılan araştırmalar, eleştirel düşünmenin yaşamın her alanında; sosyal, kültürel ekonomik ya da akademik yaşamda ne kadar önemli olduğunu açıkça göstermektedir. Bu sebeple eleştirel düşünme, öğretim programlarında yerini hızla almaya başlamıştır. Aşağıda, eleştirel düşünmenin öğretim programlarındaki yerini vurgulayan metinlerden örnekler verilmiştir.

"Eleştirel düşünme becerilerini temel alan bir yaklaşımda eğitim durumları, anlatma ve yapma gibi öğrenme yaşantıları ile değil, öğrencilerin geniş kapasiteleri için farklı öğrenme yaşantıları önerebilen bir yapıda örgütlenebilmelidir. Okullarda öğrencilere eleştirel düşünmeyi öğretme, eğitim programı aracılığıyla başarılabilir. Eğitim durumları yapılandırılırken tasarlanan ve öğrencilerin katılımı ile gerçekleştirilen etkinlikler, öğrencinin süreçten bilgi ve beceri kazanımı, düşünme değişikliği ve bireysel deneyimleri ile öğrendiklerini ilişkilendirebilme gibi öğrenme ürünleri ile ayrılmasını sağlamalıdır." (Şahinel, 2007: 55).

"Eğitim sürecinde aranan, öğrenmeyi öğrenen yani bilgiyi arayıp bulan, toplumda meydana gelen değişimlere ayak uyduran ve bu değişimlerin kaynağ yetiştirmekle görevli olan okullar, bu işi ancak, iyi yetişmiş öğretmenlerle yapabilir. Bu nedenle de her şeyden önce, öğretmenlerin 21. yüzyılda dünyada ve toplumda meydana gelen değişimlere ayak uydurmaları, bilgilerini yenilemeleri gerekir. Bir başka ifadeyle, çağdaş toplumun öğretmeni, sürekli öğrenmeyi bir ilke olarak benimseyen, çok yönlü, demokratik, sorunların üstesinden gelmeyi başaran, sorun çözme ve eleştirel düşünme becerisine sahip sınıfını aktif öğrenme ortamına dönüştürebilen özelliklere sahip olmalıdır" (Kuran, 2002; Akt; Aybek, 2006: 39).

Yukarıda bahsedilen nedenlerle, öğretmenlere büyük sorumluluklar düşmektedir. Gelişen bilim ve teknoloji ile öğretmenlerin sürekli olarak kendini geliştirmesi ve yenilemesi beklenmektedir. Bunun için öğretmen derste yorumlama, alternatif görüş araştırma, sorunları ortaya çıkarma, keşfetme, eleştirme, değerlendirme süreçleri üzerinde durmalı, yöntem çeşitliliğine gitmeli ve problem çözmeye dayalı öğretim yöntemlerine yer vermelidir. Öğrenci öğrenme sürecinde aktif hale getirilmeli, yaratıcı ve eleştirel düşünmeye imkân sağlanmalıdır.

$\mathrm{Bu}$ kavramlardan hareket edilerek, çalışmada eleştirel düşünme öğretiminin müzik eğitiminde çalg1 performansına etkilerini araştırmak, müzik öğretmenleri adaylarının eleştirel düşünme eğilimlerini saptamak,eleştirel düşünme eğitiminin müzik eğitiminde etkilerini araştırmak,eleştirel düşünme eğitimi ile müzik öğretmeni adaylarının eleştirel düşünme eğilimlerini ve müziksel performansını arttırmak amaçlanmıştır.

\section{Materyal ve Yöntem}

\subsection{Araştırmanın Modeli}

"İhtiyaç duyulan verilerin çeşitli teknikler ya da araçlar kullanılarak gözlem yoluyla toplandığı çalışmalara, görgül (ampirik) araştırmalar denir. Bir görgül araştırmada nicel ya da nitel araştırma yöntemlerinden biri kullanılabileceği gibi iki yöntem birlikte de kullanılabilir" (Büyüköztürk, Çakmak, Akgün, Karadeniz ve Demirel, 2008: 184). Araştırma, taşıdığı amaç, bu amaca uygun olarak izlenen yöntem ve toplanan verilerin niteliği açısından hem betimsel hem de deneysel bir çalışmadır.

Araştırma, deneysel araştırma modellerinden ön test - son test kontrol gruplu deneme modeline göre desenlenmiştir. Çalışmada gruplar bir deney ve bir kontrol grubu desenine göre oluşturulmuştur. Araştırma modeli, tablo1'de sunulmuştur. 
Tablo 1 : Araştırma Modeli

\begin{tabular}{|c|c|}
\hline \multirow{4}{*}{ BİRINCİ ÖLÇME } & ÖN TEST \\
\hline & 1. Kişisel Bilgi Formu \\
\hline & 2.California Eleştirel Düşünme Eğilimi Ölçeği(CCTDI) \\
\hline & 3. Performans Değerlendirme Sınavı \\
\hline $\begin{array}{l}\text { ELEŞTİREL DÜŞÜNME EĞİTIMII } \\
\text { ALMAYAN }\end{array}$ & A (kontrol grubu) \\
\hline \multirow[t]{2}{*}{$\begin{array}{lll}\text { ELEŞTİREL } & \text { DÜŞÜNME } & \text { EĞİTİMI } \\
\text { ALAN } & & \end{array}$} & B (deney grubu) \\
\hline & SON TEST \\
\hline \multirow[t]{2}{*}{ İKİNCİ ÖLÇME } & 1.California Eleştirel Düşünme Eğilimi Ölçeği(CCTDI) \\
\hline & 2.Performans Değerlendirme Sınavı \\
\hline
\end{tabular}

\subsection{Veri Toplama}

Söz konusu araştırmada, 2009-2010 öğretim yılı bahar döneminde, Gazi Üniversitesi Gazi Eğitim Fakültesi Güzel Sanatlar Eğitimi Bölümü Müzik Eğitimi Anabilim Dalı'nda okuyan ve yaşları 19 - 23 arasında değișen (Ort. $=20.85$, ss $=1.08$ ), 26's1 flüt ve 14'ü piyano öğrencisi olmak üzere toplam 40 öğrenci (38 kız, 2 erkek) üzerinde çalışılmıştır. Araştırmaya katılan, toplam 40 öğrenciye Demografik Bilgi Anketi ve California Eleştirel Düşünme Ölçeği Türkçe Versiyonu'ndan oluşan bir soru bankası sunulmuştur. Katılımcılar söz konusu sorulara yanıt verdikten sonra, alanlarında uzman olan 3 flüt ve 1 piyano olmak üzere toplam 4 müzik eğitimcisi tarafından Performans Değerlendirme Sınavına tabi tutulmuştur. Katılımcılar daha sonra, deney ve kontrol olmak üzere 2 gruba ayrılmışlardır. Deney grubuna araştırmacı tarafindan hazırlanan Eleştirel Düşünme Eğitimi verilirken, kontrol grubunda yer alan katılımcılar bu eğitimi almayarak, Yükseköğretim Kurulu (YÖK) tarafından kabul edilmiş olan 2005 yılı müzik eğitimi programındaki dersler doğrultusunda, müzik eğitimlerine devam etmişlerdir. Son aşamada, her iki gruptan da ilk başta verilen California Eleştirel Düşünme Eğilimi Ölçeği Türkçe Versiyonu'ndan oluşan soru bankasını yeniden yanıtlamaları istenmiştir. Ardından her iki grup tekrar aynı jüri tarafindan Performans Değerlendirme Sınavı'na tabi tutulmuştur.

\subsection{Verilerin Analizi}

Araştırmanın kapsamındaki deney grubu ve kontrol grubu üzerinde elde edilen veriler SPSS paket programı ile çözümlenmiştir. Verilerin aritmetik ortalamaları ve standart sapmaları betimsel olarak verildikten sonra, varyans analizi (son faktörde tekrar ölçümlü) yapılmıştır. Verileri çözümlerken, deney ve kontrol gruplarının ön test - son test puanları arasında fark olup olmadığını belirlemek için varyans analizi (son faktörde tekrar ölçümlü) kullanılmıştır.

\section{Bulgular}

$\mathrm{Bu}$ çalışma ile müzik öğretmenliği adaylarının eleştirel düşünme eğilimlerini saptamak, eleştirel düşünme öğretiminin müzik eğitiminde çalgı performansına etkilerini araştırmak, eleştirel düşünme eğitiminin müzik eğitiminde etkilerini araştırmak,eleştirel düşünme eğitimi ile müzik öğretmeni adaylarının eleştirel düşünme eğilimlerini ve müziksel performansını arttırmak amaçlanmıştır. Buradan hareketle araştırmadan elde edilen bulgular şöyledir.

\subsection{Müzik Öğretmeni Adaylarının Eleştirel Düşünme Eğiliminin Saptanmasına Yönelik Bulgular}

Araştırmanın örneklemini oluşturan ve araştırmaya gönüllü olarak katılan, Gazi Üniversitesi Gazi Eğitim Fakültesi Güzel Sanatlar Eğitimi Bölümü Müzik Eğitimi Anabilim Dalı'nda okuyan toplam 40 öğrenciye ön test aşamasında California Eleştirel Düşünme Ölçeği'nin Türkçe Versiyonu verilmiş ve sorulara yanıt vermeleri istenmiştir. Verdikleri yanıtlar sayesinde örneklemi oluşturan öğrencilerin eleştirel düşünme eğilimleri saptanmıştır. Elde edilen veriler Tablo 2'de gösterilmiştir. 
Tablo 2: Örneklemi Oluşturan Öğrencilerin Eleştirel Düşünme Ĕ̈ilimi Ortalaması ve Standart Sapmast

\begin{tabular}{lcccc}
\hline $\mathrm{n}$ & Min. & Maks. & Ort. & ss \\
\hline 40 & 218 & 315 & 264.65 & 25.81 \\
\hline
\end{tabular}

Kökdemir (2003a), California Eleştirel Düşünme Eğilimi Ölçeği’nin bir bütün olarak değerlendirildiğinde puanı 240'dan az olan kişilerin genel eleştirel düşünme eğilimlerinin düşük, puanı 300 'den fazla olanların ise bu eğilimlerin yüksek olduğunun söylenebileceğini belirtmektedir.

Buradan yola çıkılarak, örneklemi oluşturan öğrencilerin eleştirel düşünme eğilimi puanlarının ortalamasının ne düşük ne de yüksek olduğu söylenebilir $($ Ort. $=264.65$, ss $=25.81)$. Diğger bir deyişle, müzik öğretmeni adaylarının "eleştirel düşünme eğilimleri alt seviyeye daha yakın olmakla birlikte orta seviyededir" denilebilir.

\subsection{Kontrol ve Deney Grubunun Eleştirel Düşünme Eğilimi Ön test Puanlarının Saptanmasına Yönelik Bulgular}

Kontrol ve deney grupları sadece gönüllülük esasına dayanılarak belirlenmiş olduğu için ön test puanları araştırmanın sonunda karşılaştırılmıştır. Araştırmanın sonunda deney grubunda olan ve eleştirel düşünme eğitimi alan katılımcıların eleştirel düşünme eğilimi ön test puanları ortalamaları 260.22 (ss = 22.77) olarak, Kontrol grubunda olan ve eleştirel düşünme eğitimi almayan katılımcıların eleştirel düşünme eğilimi ön test puanları ortalamaları ise $255.24(\mathrm{ss}=21.70)$ olarak tespit edilmiş̧ir.Elde edilen veriler Tablo 3'de gösterilmiştir.

Tablo 3:Kontrol ve Deney Grubunda Yer Alan Öğrencilerin Eleştirel Düşünme Eğilimi Ön test Ortalamalart ve Standart Sapmalart

\begin{tabular}{llllll}
\hline Grup & $\mathrm{n}$ & Min. & Maks. & Ort. & ss \\
\hline Deney & 23 & 216 & 310 & 260.22 & 22.77 \\
\hline Kontrol & 17 & 205 & 291 & 255.24 & 21.70 \\
\hline
\end{tabular}

Kontrol ve deney grubunda yer alan öğrencilerin eleştirel düşünme eğilimi ön test ortalamaları ve standart sapmaları incelendiğinde kontrol grubunda yer alan öğrencilerin deney grubuna göre 5 puan daha az puan aldıkları görülse de bu fark istatistiksel olarak anlamlı değildir. Bu sebeple "her iki grupta olan katılımcıların eleştirel düşünme eğilimleri yaklaşık olarak aynıdır" denilebilir.

\subsection{Kontrol ve Deney Grubunun Eleştirel Düşünme EğilimiSontest Puanlarının Saptanmasına Yönelik Bulgular}

Araştırmanın amaçlarından biri, eleştirel düşünme eğiliminin verilecek olan eleştirel düşünme eğitimi ile artırılıp artırılamayacağını ortaya çıkarmaktır. Bu amaçla, deney ve kontrol olmak üzere iki gruba ayrılan katılımcılardan deney grubunda yer alanlara eleştirel düşünme eğilimlerini artırmaya yönelik eğitim verilirken, kontrol grubunda yer alan katılımcılara bu eğitim uygulanmamıştır. Söz konusu eğitimin eleştirel düşünme eğilimi üzerindeki etkisini görebilmek için, deney (eğitim alan) ve kontrol (eğitim almayan) grupları arasındaki fark dikkate alınmıştır. Bu araştırmanın varsayımı, eğitim alan katılımcıların eleştirel düşünme eğilimi puanlarının eğitim almayan katılımcılara göre daha yüksek 
olacağıdır. Deney ve kontrol gruplarının eleştirel düşünme eğilimi puanları arasında anlamlı bir farkın olup olmadığını ortaya çıkarmak amacıyla 2 (kontrol grubu - deney grubu) X 2 (ön test - son test) varyans analizi (son faktörde tekrar ölçümlü) yapılmıştır. Varyans analizi (son faktörde tekrarlı ölçüm) beklenildiği gibi anlamlı bir ortak etkinin varlı̆̆ını göstermiştir $\left(\mathrm{F}_{1,38}=4.55, \mathrm{p}<.05\right)$. Diğer bir ifadeyle eleştirel düşünme eğitiminin, katılımcıların eleştirel düşünme eğilimi puanlarını yükselttiği söylenebilir. Varyans analizi tablosu aşağıda gösterilmiştir (bkz. Tablo 4).

Tablo 4:Eleştirel Düşünme Eğiliminin Kontrol ve Deney Gruplarında Ön test ve Son test Farklılıklarını Gösteren Varyans Analizi Sonuçları

\begin{tabular}{llllll}
\hline Kaynak & $\begin{array}{l}\text { Kareler } \\
\text { Toplamı }\end{array}$ & s.d. & $\begin{array}{l}\text { Ortalama } \\
\text { Kare }\end{array}$ & $F$ & $p$ \\
\hline Test (ön test/son test) & 618.93 & 1 & 618.93 & 3.80 & .06 \\
Grup (deney/kontrol) X Test & 740.88 & 1 & 740.88 & 4.55 & .04 \\
Hata & 6191.07 & 38 & 162.92 & & \\
\hline
\end{tabular}

Tabloda da görüldüğü üzere, deney grubunda olan ve eleştirel düşünme eğitimi alan katılımcıların eleştirel düşünme eğilimi puanları ortalamaları ilk başta $260.22(\mathrm{ss}=22.77)$ iken, bu ortalama daha sonra 272.00'ye $(\mathrm{ss}=21.99)$ yükselmiştir $(\mathrm{n}=23)$. Kontrol grubunda olan ve eleştirel düşünme eğitimi almayan katılımcıların eleştirel düşünme eğilimi puanları ortalamaları ilk başta 255.24 (ss = 21.70) iken, bu ortalama daha sonra $254.71(\mathrm{ss}=27.87)$ olarak tespit edilmiştir $(\mathrm{n}=17)$.

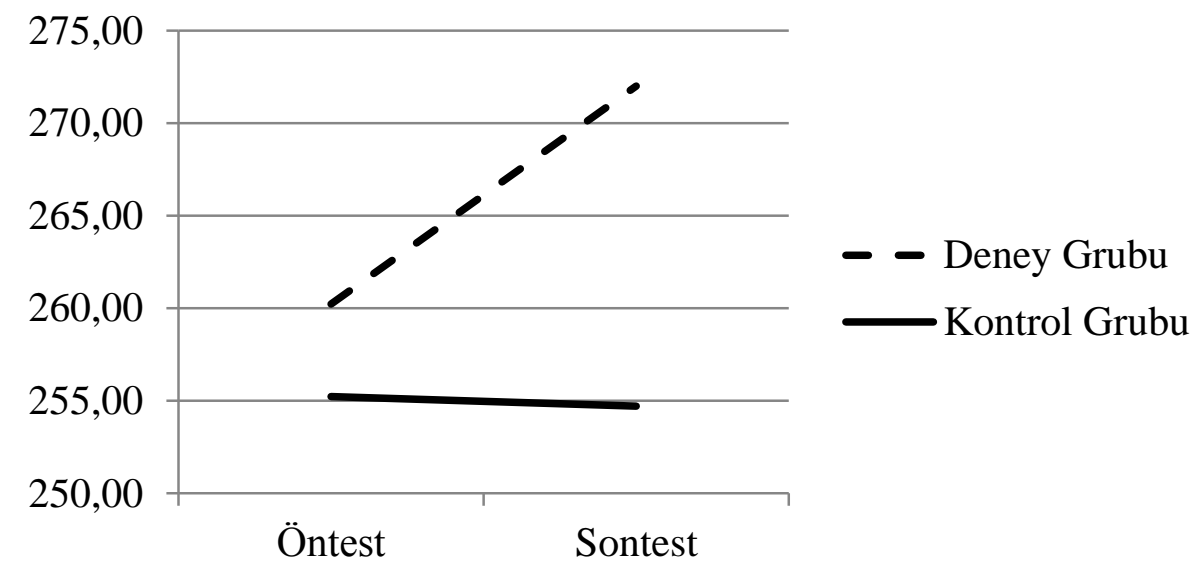

Şekil 1:Kontrol Grubu - Deney Grubu ve Ön test - Son test Arasındaki Etkileşim

Diğer bir deyişle, eleştirel düşünme eğitimi verilmeden önce kontrol grubu ile deney grubu hemen hemen aynı ortalama ile çalışmaya katıldığı görülmektedir. Eleştirel Düşünme Programı uygulanan deney grubu ile Eleştirel Düşünme Programı uygulanmayan kontrol grubunun "eleştirel düşünme eğilimi " son test puanları anlamlı düzeyde fark vardır. Deney grubunun son test puanları ortalaması ön test puanları ortalamasına göre oldukça yükselirken, kontrol grubunun son test puanları ortalaması ön test puanları ortalamasıyla karşılaş̧ırıldığında ortalamanın sabit kaldığı görülmektedir. Eleştirel düşünme eğitimi alan deney grubu öğrencilerinin son test puanları, eleştirel düşünme eğitimi almayan kontrol grubu öğrencilerinin son test puanlarına göre oldukça yüksektir. Bu sonuçtan yola çıkılarak verilen eleştirel düşünme eğitimiyle, öğrencilerin eleştirel düşünme eğilimlerinin oldukça arttırdığ1 söylenebilir. 


\subsection{Eleştirel Düşünme Öğretiminin Müzik Eğitiminde Çalgı Performansına Etkilerinin Saptanmasına Yönelik Bulgular}

Araştırmanın genel amacı, eleştirel düşünmenin performans üzerindeki etkisini test etmektir. Diğer bir ifadeyle, eleştirel düşünme eğitimi verilerek eleştirel düşünme eğilimlerinde artış sağlanmaya çalışılan öğrencilerin performanslarında da bir fark olup olmadığını ortaya çıkarmaktır. Bu amaçla, eleştirel düşünme eğilimlerini artırmaya yönelik eğitim verilen deney grubunda yer alan öğrenciler ile söz konusu eğitim uygulaması yapılmayan kontrol grubunda yer alan öğrencilere, araştırmanın başında ve sonunda olmak üzere iki defa Performans Değerlendirme Sınavı uygulanmıştır. $\mathrm{Bu}$ sınavda ögrencilerin performansları, alanlarında uzman olan 3 flüt ve 1 piyano olmak üzere toplam 4 müzik eğitimcisi tarafindan değerlendirilmiştir. Eleştirel düşünme eğitiminin öğrencilerin performansları üzerindeki olası etkisini görebilmek için deney (eğitim alan) ve kontrol (eğitim almayan) grupları arasındaki farka bakılmıştır. $\mathrm{Bu}$ araştırmanın varsayımı, eğitim alan katılımcıların performans puanlarının eğitim almayan katılımcılara göre daha yüksek olacağıdır. Deney ve kontrol gruplarının performans puanları arasında anlamlı bir farkın olup olmadığını ortaya çıkarmak amacıyla 2 (kontrol grubu - deney grubu) X 2 (ön test - son test) varyans analizi (son faktörde tekrar ölçümlü) yapılmıştır. Varyans analizi (son faktörde tekrarlı ölçüm) beklenildiği gibi anlamlı bir temel etkinin $\left(\mathrm{F}_{1,38}=78.71\right.$, $\mathrm{p}<.05)$ ve test - grup ortak etkisinin varlığını göstermiş̧tir $\left(\mathrm{F}_{1,38}=58.89, \mathrm{p}<.05\right)$. Varyans analizi tablosu aşağıda gösterilmiştir (bkz. Tablo 5).

Tablo 5:Katılımcıların Performans Değerlendirme Sinavi Puanlarının Kontrol ve Deney Gruplarında Öntest ve Sontest Farklılıklarını Gösteren Varyans Analizi Sonuçları

\begin{tabular}{lccccc}
\hline Kaynak & Kareler & s.d. & Ortalama & \multirow{2}{*}{ Kare } & \\
& Toplamı & & Kare & \\
\hline Test (öntest/sontest) & 2906.53 & 1 & 2906.53 & 78.71 & .001 \\
Grup (deney/kontrol) X Test & 2174.33 & 1 & 2174.33 & 58.89 & .001 \\
Hata & 1403.16 & 38 & 36.92 & & \\
\hline
\end{tabular}

Aşağıda yer alan Şekil 2'de de görüldügü üzere, deney grubunda olan ve eleştirel düşünme eğitimi alan katılımcıların Performans Değerlendirme Sınavı puanları ortalamaları ilk başta 64.35 (SS = 8.95) iken bu ortalama daha sonra 87.09'a $(\mathrm{SS}=9.16)$ yükselmiş̧ir $(\mathrm{n}=23)$. Kontrol grubunda olan ve eleştirel düşünme eğitimi almayan katılımcıların Performans Değerlendirme Sınavı puanları ortalamaları ilk başta $69.65(\mathrm{SS}=10.83)$ iken bu ortalama daha sonra $71.29(\mathrm{SS}=13.76)$ olarak tespit edilmiştir $(\mathrm{n}=17)$.

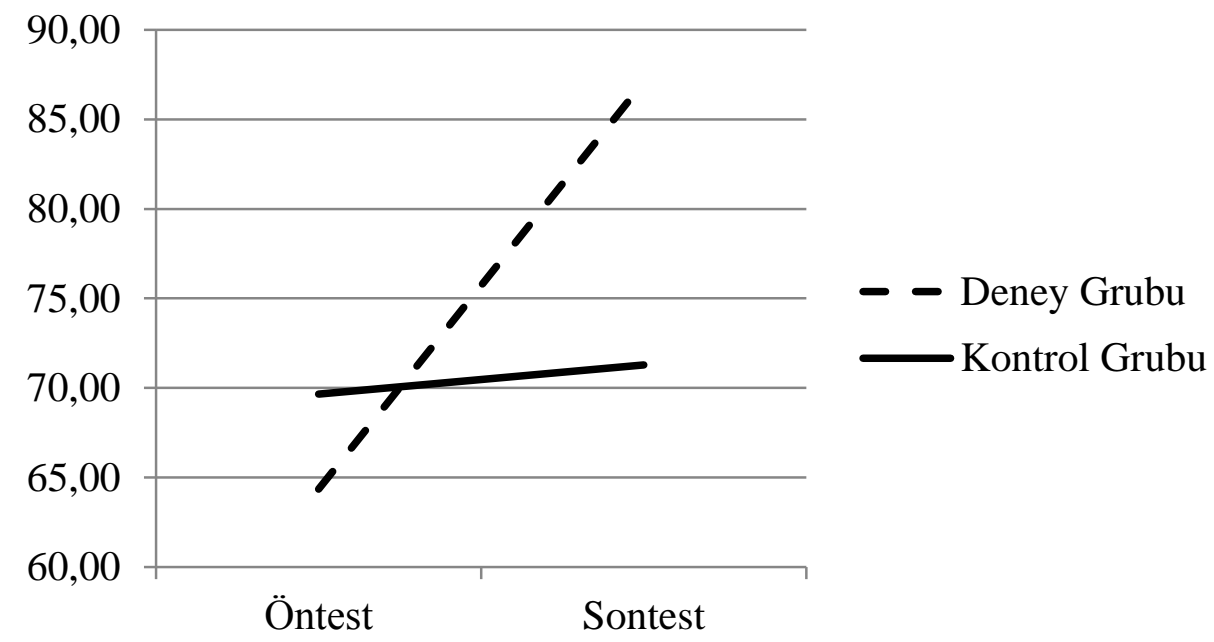

Şekil 2: Kontrol Grubu - Deney Grubu ve Öntest - Sontest Arasındaki Etkileşim 
Başka bir ifadeyle öğrencilerin Performans Değerlendirme Sınavı ön ve son test puanları arasında anlamlı bir fark bulunmaktadır. Bu durumda 10 hafta boyunca araştırmacı tarafından verilen eleştirel düşünme eğitiminin, katılımcıların performans puanlarını oldukça yükselttiği görülmektedir. Buradan hareketle, araştırmanın ana problemine göre, müzik öğretmeni adaylarının çalgı performansları eleştirel düşünme eğitimi ile oldukça artmaktadır.

\subsection{Deney Grubuna Eleştirel Düşünme ProgramıUygulanmadan Önce Ve Uygulandıktan Sonra Öğrencilerin Eleştirel Düşünme Kavramına İlişkin Algılarına Yönelik Bulgular}

Eleştirel Düşünme Programı uygulanmadan önce ve uygulamalar bittikten sonra, öğrencilerin "eleştirel düşünme" kavramının ne olduğuna yönelik görüşlerini belirlemek için, uygulamanın ilk dersinde ve son dersinde öğrencilere "Eleştirel düşünme nedir?" sorusu sorulmuş ve öğrencilerin düşüncelerini yazılı olarak ifade etmeleri istenmiştir.

Deney grubundaki öğrencilerin dönemin başında ve sonunda bu soruya verdikleri yanıtlar irdelenerek ve araştırmacının süreç boyunca elde ettiği gözlemlere dayalı olarak aşağıdaki tartışma ve yorumlar yapılmıştır.

Öğrencilerin uygulamadan önce eleştirel düşünmeyi daha dar bir kapsamda ele alırken, uygulama sonrasında bu kavramı daha bilimsel, daha geniş ve farklı boyutları ile ele aldıkları görülmüştür. Öğrenciler ilk derslerde eleştirel düşünme kavramını sadece olumsuz eleştiri kavramıyla bağdaştırmışlar, düşüncelerini söylemede çekingen bir tavır sergilemişlerdir. Dersler ilerledikçe kendilerini ve düşüncelerini daha rahat ifade eden öğrenciler, gerek sözel, gerekse de yazılı olarak daha yaratıcı, daha bilimsel tanımlar yapmaya başlamışlardır.

Aşağıda öğrencilerin 10 haftalık Eleştirel Düşünme Programı uygulanmadan önceki ve uygulandıktan sonraki eleştirel düşünme algılarına yer verilmiştir. Bu tanımlar öğrencilerin doğrudan kendi ifadeleridir.

\section{Öğrencilerin 10 haftalık Eleştirel Düşünme Programı uygulanmadan önceki eleştirel düşünme algıları:}

- Eleştirel düşünme; bazen çok gerekli ama bazen de her güzelliğin içinde bir hata ararcasına çabalamak.

• Eleştirel düşünme; gerçekten düşünmektir.

- Eleştirel düşünme; her şeyi olduğu gibi kabullenmemek, araştırmak.

• Eleştirel düşünme; tüm detaylarla düşünmektir.

\section{Öğrencilerin 10 haftalık Eleştirel Düşünme Programı uygulandıktan sonraki eleștirel düşünme algıları:}

- Bir nesneye ya da olaya farklı açılardan bakarak, onun neden ve sonuçlarını gözden geçirip farklı yorumlarda bulunabilmek.

- Eleştirel düşünme; karşımıza çıkan durumu olayı ya da bilgiyi olduğu gibi kabul etmeyip, kapsamlı bir şekilde araştırarak belirli ölçütlere dayandırmak.

- Eleştirel düşünmeyi yeryüzündeki koordinatlarım, coğrafi konumum olarak tanımlayabilirim.

- Bir bilginin ya da olayın nedenini, sonucunu, farklı bakış açılarıyla analiz ederek yorumlama, tartışma süreci.

- Eleştirel düşünme; tek bir doğruya takılıp kalmadan, alternatifleri de değerlendirme, analiz etme, yorumlama. 


\subsection{Deney Grubunun Eleştirel Düşünme Dersinin İşlenişine İlişkin Görüşlerine Yönelik Bulgular}

Uygulamaların bittiği 10. haftada, deney grubundaki öğrencilere ölçme araçları uygulanmış ve ardından öğrencilerden "dersin işlenmesine yönelik görüşlerini” yazılı olarak ifade etmeleri istenmiştir.

Deney grubundaki öğrencilerin verdikleri yanıtlar irdelenerek ve araştırmacının süreç boyunca elde ettiği gözlemlere dayalı olarak aşağıda tartışma ve yorumlar yapılımıştır.

Öğrencilerin dersin işlenmesine ilişkin görüşleri incelendiğinde genel olarak derste yapılan eleştirel düşünme etkinliklerine istekle katıldıkları, derse karşı olumlu tutum içinde oldukları, bir başka deyişle bu dersten zevk aldıkları ve memnun oldukları söylenebilir. Öğrencilerin dersler ilerledikçe etkinliklere yönelik daha yaratıcı olmaları, eleştirel düşünmeyi zamanla yaşamları içerisine dâhil ettiklerini, gerek sözel olarak gerekse de davranışlarıyla ifade etmeleri, araştırmaya katılımda hiçbir zorunluluk olmamasına rağmen gönüllü olarak 10 hafta boyunca hiç devamsızlık yapmadan çalışmalara devam etmeleri, derslere karşı olumlu bir tutum sergilediklerini ortaya koymaktadır.

Öğrencilerin kendilerini ve fikirlerini bu derste rahat bir şekilde ifade etmeleri, yaratıcı fikirler üretmeleri, düşüncelerini hiçbir şekilde kısıtlamamaları, derslerde ezberci bir eğitim yerine öğrencinin merkezde olduğu bir öğretim yönteminin izlenmiş olması, farklı bakış açılarına yer verilerek sık sık tartışma yönteminin kullanılması, öğrencilerin bu dersten daha fazla zevk almasına sebep olmuştur.Hatta öyle ki yapılan dersler öğrencilerin istekleri doğrultusunda hiç ara verilmeden blok olarak yapılmış, zaman zaman bu dersler haftada 2 saat olarak planlanmış olmasına rağmen 3 saate kadar uzatılmıştır. Öğrencilerin memnuniyeti ve derse istekle katılımları, dersin akışını hızlandırarak çok keyifli çalışmaların yapılmasına imkân tanımıştır.

Deney grubundaki öğrencilerin dersin işlenmesine yönelik görüşleri incelendiğinde hemen hemen tüm öğrenciler; bu dersin ve bu derste kazandırılmaya çalışlan eleştirel düşünme becerilerinin, tüm öğretmen ve öğretmen adaylarına kazandırılması gerektiğini, "Eleştirel Düşünme Eğitimi” dersinin zorunlu bir ders olarak lisans eğitiminde verilmesi gerektiğini, hatta imkânlar dâhilinde bu eğitimin daha alt eğitim kademelerinde de verilmesi gerektiğini belirtmişlerdir.

Öğrenciler, yapılan sohbetlerde, verilen eleştirel düşünme eğitimini günlük yaşamlarında da kullandıklarını, insanlarla iletişimde bulunurken, yaşamla ilgili önemli kararlar alırken bu eğitimin gerçekten yararını gördüklerini, müzik eğitimlerinde fark yaratacak önemli kararlar aldıklarını, hayatlarında farkındalık yaşadıklarını, sorgulamayı öğrendiklerini, müzik yaşantılarında kendilerini artık daha iyi ifade edebildiklerini ya da en azından etmeye çalıştıklarını, kendilerine ait doğru çalışma yöntemlerini keşfetmeye başladıklarını ifade etmişlerdir.

Aşağıda öğrencilerin kendi ifadeleri ile yazılı olarak verdikleri "dersin işlenişine ilişkin görüşleri” doğrudan alıntılanarak verilmiştir.

- Derslerin sonunda bu çalışmanın bana çok şey kattığını, uzun zamandır aklımda olan örtülü düşüncelerimin gün 1şığına çıktığını ve onları gerçekten uygulamaya başladığımı fark ettim. Bu tür çalışmalar lisans programlarında da bir ders olarak yer alabilir...

- Keşke sadece bizde değil, bu dersle okulun tamamında bir değişim olsaydı...

- Keşke devam etse bitmese, burada olamayan insanlarda böyle bir çalışmayı uygulamayı hak ediyor...

- Kısa olduğunu düşünmekle birlikte öz olduğunu da düşünüyorum. Gerçekten tahminimden çok çok daha yararlı bir çalışma oldu...

- Bu dersten kazandıklarımı hayatım boyunca yaşamımın her köşesinde kullanacağıma emin olabilirsiniz...

- Bu çalışma aslında var olduğunu bildiğim pencerelere yaklaşıp, onları daha sık açmamı sağladi... 
- Eleştirel düşünmenin hayatımı bu kadar değiştireceğini düşünmezdim. Yaşamımda farklı pencereler açılmış oldu...

- Kesinlikle sözlerle ifade edilemeyen, davranışsal olaylar bu çalışmada öğrenilenler. Adeta hayata üç boyutlu gözlükle bakmak gibi bir şey.. Daha eğlenceli ve gerçek...

- Dinlemeyi, insanların düşündüklerine hemen karşı çıkmamayı ve en önemlisi sorgulamayı öğrendim...

- Gerçekten çok teşekkürler hocam, hayatımda yeni renklere yer açmamı sağladığınız, kendimle beni yüzleştirdiğiniz ve insanları dinlemeyi öğrettiğiniz için...

- Keşke 4 yıl boyunca bu dersi alabilsek...

\section{Sonuçlar}

Araştırma kapsamında eleştirel düşünme eğilimleri saptanan 40 katılımcının eleştirel düşünme eğilimi puanlarının ortalamasının ne düşük ne de yüksek olduğu söylenebilir (Ort. = 264.65, ss = 25.81). Diğer bir deyişle, müzik öğretmeni adaylarının "eleştirel düşünme eğilimlerinin alt seviyeye daha yakın olmakla birlikte orta seviyede" olduğu saptanmıştır.

Deney grubunda olan ve eleştirel düşünme eğitimi alan katılımcıların eleştirel düşünme eğilimi puanları ortalamalarının ilk başta $260.22(\mathrm{ss}=22.77)$ iken bu ortalamanın daha sonra 272.00 'ye (ss $=$ 21.99) yükseldiği görülmektedir $(n=23)$. Kontrol grubunda olan ve eleştirel düşünme eğitimi almayan katılımcıların eleştirel düşünme eğilimi puanları ortalamaları ilk başta 255.24 (ss = 21.70) iken bu ortalama daha sonra $254.71(\mathrm{ss}=27.87)$ olarak tespit edilmiştir $(\mathrm{n}=17)$. Diğer bir ifadeyle eleştirel düşünme eğitiminin, katılımcıların eleştirel düşünme eğilimi puanlarını yükselttiği görülmektedir.

Deney grubunda olan ve eleştirel düşünme eğitimi alan katılımcıların Performans Değerlendirme Sınavı puanları ortalamaları ilk başta $64.35(\mathrm{ss}=8.95)$ iken bu ortalama daha sonra 87.09'a $(\mathrm{ss}=9.16)$ yükselmiştir $(\mathrm{n}=23)$. Kontrol grubunda olan ve eleştirel düşünme eğitimi almayan katılımcıların performans değerlendirme sınavı puanları ortalamaları ilk başta $69.65(\mathrm{ss}=10.83)$ iken bu ortalama daha sonra $71.29(\mathrm{ss}=13.76)$ olarak tespit edilmiştir $(\mathrm{n}=17)$. Başka bir ifadeyle öğrencilerin Performans Değerlendirme Sınavı ön ve son test puanları arasında anlamlı bir fark bulunmaktadır. Bu durumda 10 hafta boyunca araştırmacı tarafından verilen eleştirel düşünme eğitiminin, katılımcıların performans puanlarını oldukça yükselttiği görülmektedir. Buradan hareketle, araştırmanın ana problemine göre, "müzik öğretmeni adaylarının çalgı performanslarının eleştirel düşünme eğitimi ile oldukça arttı̆̆ı" söylenebilir.

\section{5. Öneriler}

$\mathrm{Bu}$ araştırmanın sonuçları incelendiğinde, eleştirel düşünme eğitiminin müzik eğitiminde çalg1 performansını olumlu yönde etkilediği, performans değerlendirme sınavının sonuçlarını oldukça yükselttiği görülmektedir. Katılımcıların çalgı performanslarının artması, mesleki olarak kendilerini daha yeterli hissetmelerini sağlamaktadır. Alanlarında kendine güvenen müzik öğretmenlerinin, mesleki yaşantılarında çok daha başarılı olmaları muhtemeldir. Buradan hareketle eleştirel düşünme eğitiminin, sadece müzik eğitiminde değil, sanatın diğer alanlarında ve eğitim fakültelerinin tüm bölümlerinde öğretilmesi sağlanabilir.

Deney grubunda yer alan katılımcıların eleştirel düşünme eğitimi ile ilgili görüşleri alındığında öğrenciler; aldıkları eleştirel düşünme eğitimini sadece çalg1 eğitimlerinde değil, diğer mesleki derslerde de kullanmaya başladıklarını ifade etmişlerdir. $\mathrm{Bu}$ sonuca göre, öğrencilerin eleştirel düşünme becerilerinin daha fazla geliştirilebilmesi için müzik eğitiminde verilen alan dersleri birbirleriyle koordineli olarak işlenerek, tüm derslerde eleştirel düşünme becerilerini kazandırmaya yönelik etkinlikler ve öğretme stratejileri kullanılabilir.

- Eleştirel düşünme becerilerini tam ve kalıcı olarak öğrencilere kazandırabilmek için bu beceriler ayrı ders olarak da lisans eğitiminde verilebilir. 
- Araştırmanın örneklem grubunu üniversitedeki öğrenciler oluşturmuştur. Fakat aynı çalışma, ortaöğretimdeki Anadolu Güzel Sanatlar ve Spor liselerindeki öğrenciler üzerinde de yapılabilir.

- Bu araştırmada, ölçme aracı olarak California Eleştirel Düşünme Eğilimi Ölçeği kullanılmıştır. Aynı araştırma farklı eleştirel düşünme ölçme araçları kullanılarak tekrarlanabilir.

- Araştırmanın, müzik eğitiminde öğretmen adaylarının eleştirel düşünme eğilimi ölçen ilk çalışma olması büyük önem taşımaktadır. Bu çalışmanın ardından eleştirel düşünme eğitimi genelde sanat eğitiminin özelde ise müzik eğitimi alanındaki tüm öğrencilere öğretilmesi sağlanabilir.

- Eğitim fakültelerindeki öğretim elemanlarının kendi dersleri içerisinde eleştirel düşünme becerisini nasıl kazandırabilecekleri konusunda yardımcı olması amaciyla, seminerler ve konferanslar düzenlenebilir.

- Bu alandaki ölçme araçları az olduğundan alana yönelik araştırmalar daha çok yapılabilir ve ölçme araçları geliştirilebilir.

- Eğitim fakültelerinde eleştirel düşünmeyi temel alınarak; eleştirel okuma, eleştirel yazma, eleştirel dinleme gibi seçmeli dersler konulabilir.

- Gerek müzik eğitimi anabilim dallarında, gerekse eğitim fakültelerinin tüm bölümlerinde, düşünme becerilerini ön plana çıkaran, problem çözme, yaratıcı düşünme ve eleştirel düşünme becerileri içerikli dersler verilebilir. 


\section{KAYNAKLAR}

AKBIYIK, Cenk, (2002). Eleştirel Düşünme Eğilimleri ve Akademik Başarı, Ankara, Yayınlanmamış Yüksek Lisans Tezi, Hacettepe Üniversitesi Sosyal Bilimler Enstitüsü.

AYBEK, Birsel, (2006). Konu ve Beceri Temelli Eleştirel Düşünme Öğretiminin Öğretmen Adaylarının Eleştirel Düşünme Eğilimi ve Düzeyine Etkisi, Adana, Yayınlanmamış Doktora Tezi, Çukurova Üniversitesi Sosyal Bilimler Enstitüsü.

BÜYÜKÖZTÜRK, Şener, ÇAKMAK, Ebru Kılıç, AKGÜN, Özcan Erkan, KARADENIZ, Şirin, DEMIREL, Funda, (2008). Bilimsel Araştırma Yöntemleri. Ankara: Pegem A Akademi.

CHAFFEE, John (1992). Critical ThinkingSkills: TheCornerstone of DevelopmentalEducation. Journal of DevelopmentalEducation, 15.3: 2.

CHANCE, Paul (1986). "Introduction: TheThinkingMovement" Thinking in theClassroom: A Survey of Programs. P.Chance\& R.S. Brandt (Ed). New York: TeachersCollegePress.

CÜCELOĞLU, Doğan (1995). İyi Düşün Doğru Karar Ver. İstanbul: Sistem Yayıncılık.

ÇAKMAK, Hasan (2002). İlköğretim Okullarında Düşünme Eğitimi - Cumhuriyet Dönemi, Diyarbakır, Yayınlanmamış Yüksek Lisans Tezi, Dicle Üniversitesi Sosyal Bilimler Enstitüsü.

DENIZ, Taşkın(2003). Coğrafya Öğretiminde EleştirelDüşünme Yönetiminin Başarıya Etkisi, Ankara, Yayınlanmamış Yüksek Lisans Tezi, Gazi Üniversitesi Eğitim Bilimleri Enstitüsü.

GIBSON, Craig (1995). Critical Thinking: ImplicationsforInstruction. RQ, 35 no1.

KEPENEKÇİ, Yasemin Karaman (2000). İnsan Hakları Eğitimi. Ankara: Kozan Ofset.

KÖKDEMİR, Doğan (1999). Üniversitede Bir Eleştirel Düşünme Yöntemi. Cumhuriyet Bilim Teknik, s.632.

KÖKDEMİR, Doğan (2003a). Belirsizlik Durumlarında Karar Verme ve Problem Çözme, Ankara, Yayınlanmamış Doktora Tezi. Ankara Üniversitesi, Sosyal Bilimler Enstitüsü.

KÖKDEMIR, Doğan (2003b). Eleştirel Düşünme ve Bilim Eğitimi, PiVOLKA, 2(4),3-5.

KURAN, Kezban (2002). "Öğretmenlik Mesleği (niteliği ve özellikleri), Adil Türkoğlu (Ed.), Öğretmenlik Mesleğine Giriş, Ankara: İnci Ofset.

Milli Eğitim Bakanlığı (2005). İlköğretim 1-5. Sınıf Programları, Ankara.

PAUL, Richard. Critical thinking: What, why, and how. New DirectionsforCommunityColleges, 1992, 1992.77: 3-24.

ŞAHINEL, Semih (2007). Eleştirel Düşünme Ankara: Pegem A Yayıncılık.

TAŞCI, Sultan (2005). "Hemşirelikte problem çözme süreci”, Erciyes Üniversitesi Sağlık Bilimleri Dergisi Hemşirelik Özel Sayısı, 14: 73-78.

TÜRK DİL KURUMU, (2005). Türkçe Sözlük, Ankara: TDK. 